\title{
The Availability and Utilization of E-Learning Infrastructures for Teaching and Learning
}

\author{
Olusesan A. Adelabu \\ Department of Microbiology, University of Fort Hare, South Africa \\ seccie2003@yahoo.com \\ Prof Emmanuel O.Adu Phd \\ School of Continuing and General Education, University of Fort Hare, South Africa, \\ eadu@ufh.ac.za \\ Shadrack J. Adjogri \\ Department of Chemistry, University of Fort Hare, South Africa \\ sadjogri@ufh.ac.za
}

Doi:10.5901/mjss.2014.v5n23p1348

\section{Abstract}

The increased involvement of technology in all aspects of our lives places educational institutions under pressure to include these aspects at the heart of their learning. This ensures that they continue to be competitive in a constantly changing market with international and cultural links and the organizational infrastructure often presents the greatest barrier to such developments. Although the Government is committed to implementing ICT in education, the process seems to be militated by a number of barriers hence this study investigated the availability and utilization of e-learning infrastructures for teaching and learning at the University of Ibadan. Four research questions guided the study. The population of the study was made up of 482 students and 180 lecturers randomly selected from the four faculties of the institution. Data obtained was analyzed using mean and t-test. Some of the findings revealed that e- learning infrastructures are not adequate in the higher institution of learning. Development of Information and Communication Technology (ICT) is mainly for administrative purposes. In addition, both lecturers and students have computers and laptops which could be used to access the internet but, they do not use them for teaching and learning. Based on the findings of the study, recommendations were made to encourage the use of e-learning infrastructures to foster teaching and learning in the university. The university should as matter of urgency organize in house training for lecturers on the use of ICT for teaching and learning. Government should release the necessary funds to enable universities put in place necessary ICT infrastructures that will facilitate teaching and learning.

Keywords: ICT, infrastructure, availability, e-learning and utilization

\section{Introduction}

Undoubtedly, the implementation of e-learning systems in higher education has enabled a dramatic change in teaching and learning practice. The success of e-learning adoption across an organization depends on several factors, for example, the availability of technology, how students and instructors are supported in its use and the integration of technology within the student learning experience. Transformation of the learning style presents several challenges including changes in the cultural expectations and the continuing development of technological skills of staff and students. These aspects need to be managed and implemented effectively to achieve overall enrichment of student and staff learning experiences, which are enhanced through the appropriate use of technological blends.ICT is also becoming increasingly prominent in tertiary education. Rationales for its growth are wide-ranging, complex and contested, including widening access, on-campus pedagogic innovation, enhancement of distance learning, organizational change, knowledge-sharing and revenue generation.( Forcheri and Molfino, 2000),however integration and utilization of well managed infrastructures are needed for the materialization of its intended purpose its of invention, in our higher institutions of learning.

Information and Communication Technology (ICT) have become key tools in educational methodology and curriculum delivery globally. It has been identified as an indispensable tool for the development of quality teaching and learning in the education system. ICT is fundamental for the preparation of students in meeting the innovations in the 
global arena (Ololube, 2006). The growth of information and communication technologies has dramatically reshaped teaching and learning processes in higher education (Pulkkinen. 2007 \& Wood.1995). The application of ICT in higher institutions is more critical today than ever before since its growing power and capabilities are triggering a change the learning environments in education (Pajo \& Wallace, 2001). The use of ICT offers powerful learning environments and can transform the learning and teaching process so that students can deal with knowledge in an active, self-directed and constructive way (Volman \&Van Eck, 2001; de Corte et al 2003). At present ICT is considered as an important means of promoting new methods of instruction i.e. teaching and learning. It should be used for the development of students' skills for cooperation, communication, problem solving and lie long learning (Plomp, 1996 \&Vogot. 2003). The application of ICT to education has given rise to a new set of vocabularies used to describe new approaches to learning and curriculum delivery. Such terms include e - teaching, e - learning, e-tag, e- cards, white board, web classroom which are facilitated via the internet. The availability of the internet provided the channel for the use of electronic approach to education known as electronic learning or e - learning. Simply put, e - learning is the process of teaching and learning using the computer via internet. It involves passing structured instructional materials from a repository to a learner. According to Erah (2006), e- learning refers to computer - enhanced training as opposed to the computer - based training of the 1980s. It is usually delivered in a personal computer and includes learning delivered by other communication technologies. To him, elearning is an approach to facilitate and enhance learning through both computer and communication technologies.

Rosenberg (2001).e- learning as the appropriate application of the internet to support the delivery of skills and knowledge in a holistic approach not restricted to a particular courses, technologies or infrastructure. Communication technologies include all media employed in transmitting audio, video, data or multimedia such as cable satellite, fibre optics, wireless (radio, infra - red, Bluetooth, Wi-Fi). Network technologies on the other hand include: Personal Area Networks (PAN), Campus Area Network (CAN), intranets, extranets, Local Area Networks (LANs), Wide Area Networks (WANs) and the internet. Computer technologies include all removable media such as optical discs, disks, flash memories, video books, multimedia projectors, interactive electronic boards, and continuously emerging state-of-the art personal computers (PCs). Mobile technologies such as mobile phones, Personal Digital Assistants (PDAs), palmtops, etc. which have information as their material object are also used in e-learning (Freedman, 2001).

ICT, according to Newhouse (2002b) promote active learning as it develops an appropriate level of capability in students making it possible for them to become more engaged with their own learning, and to achieve learning outcomes across the curriculum. He went on to point out that it support pedagogical practices that provide learning environments that are more learner-cent red, knowledge-centered, assessment-centered, and community centered. PT3 (2002) see ICT as a tool that facilitates learning and enhance student achievement and teacher learning if appropriately used. This is because e-learning is learner-centered and supports New Learning Environments (NLE) which is a departure from the Traditional Learning which is teacher centered. Learning with ICT, also known as e-learning, enrich learning content and enhance wider access to information resources. When the potential of e-learning is fully harnessed, it could advance knowledge by expanding and widening access, improving the quality of education and reducing cost (Newhouse, 2002a). When the needs are huge, fully online learning can be crucial and possibly the only realistic means of increased and widened access to tertiary education. For developing countries like Nigeria which has many young people craving for tertiary education and limited number of tertiary institutions to meet demand, e-learning has the potential to accommodate every candidate to study. Pirani (2004) stated that for an institution to be able to adopt e-learning it must provide adequate and reliable technical infrastructure to support e-learning tools and instructors and students must possess the technical skills to use e-learning. Instructors must also redesign their courses to incorporate e-learning effectively into their pedagogy. This has to be supported by relevant policy and legislature from government in order to merit wide acceptability. In Nigeria, this was achieved by the approval of the National Information Technology Policy (NITP) in March 2001 and the subsequent establishment of the National Information Technology Development Agency (NITDA) to implement NITP in April 2001 (Wodi, 2009).

The policy stipulated the relevance of ICT to tertiary education. To further strengthen the impact of the policy, the National Universities Commission (NUC), which is the government agency responsible for the regulation of universities in Nigeria prescribed PC ownership for universities as follows: one PC to every four students, one PC to every two lecturers below lecturer I; one PC per senior lecturer, and one notebook per reader/professor (Agyeman, 2007). According to Agyeman (2007), only few universities such as Nnamdi Azikwe University have achieved a better ratio for their faculty but not for PC-to-student ratio. He pointed out however that some universities have made giant strides in campus-wide area networking and e-learning deliveries. A campus like Obafemi Awolowo University (OAU) has its own VSAT and has embarked on progressive application of ICT to all its functions. Similarly, University of Jos (UNIJOS) has an e-learning web site for the Department of Anatomy that permits students to undertake virtual electronic dissections. Despite these laudable achievements by some universities the story cannot be said to be the same across all university campuses in 
Nigeria. It is against this background that this study aims at investigating the availability and utilization of e-learning infrastructures for teaching and learning at the University of Ibadan.

\section{Statement of the Problem}

Research has shown that computers enhance teaching and learning by providing opportunities to practice and to analyze, offering better access to relevant articles, teaching and learning materials. Above all Rosswall,(1999) while stressing the importance ICT in a tertiary institution said ICT enhances higher education in a number of ways: It enables the effective storing/ sorting of information, and can offer new fast ways of communication; the reduction of information quantity towards a higher quality and better structure; it can be integrated into teaching and learning strategies - and used to support relative learning theories and ICT (computers, Inter and Intranet) can be used to create new types of interactive learning media for improved quality, equity and access in higher education. Despite the obvious and enormous advantages that comes with using ICT in teaching and learning. Shahadat, Muhbub and Clement (2012) observed with great concern that several higher educational institutions are finding it difficult to even implement basic of ICT. ICT facilities in teaching and learning are nowhere to be found. This coupled with limited infrastructure to support e-learning and ICT application in University of Ibadan. UI prompted this study.

\section{Purpose of the Study}

The objective of the study was to investigate the availability and utilization of e-learning infrastructures at University of Ibadan. Nigeria. Specifically, the study investigated:

1. Adequacy of e-learning infrastructures for effective teaching and learning.

2. The proficiency of the use of e-learning infrastructures to facilitate teaching and learning by lecturers.

3. The proficiency of the use of e-learning infrastructures to enhance learning by students.

4. Factors that inhibit the use of e-learning infrastructures.

\section{Research Questions}

The following research questions were raised to guide the study:

1. To what extent are e-learning infrastructures adequate in UI?

2. How proficient are lecturers in the use of e-learning infrastructures in teaching and learning?

3. How proficient are students in the use of e-learning infrastructures to enhance their learning?

4. What are the factors that inhibit the use of e-learning infrastructure at UI?

\section{Hypothesis}

The following null hypothesis was tested at 0.05 significance level:

$\mathrm{HO}_{1}$ : There is no significant difference in the mean response of lecturers and students on the availability of elearning infrastructures.

\section{Methodology}

The study used a descriptive survey research design. A sample of 180 lecturers and 482 students were sampled randomly and used as respondents for the study. A 64-item structured questionnaire known as Availability and Utilization of E-learning Infrastructures Questionnaire (AU-ELIQ) was used to obtain data from respondents for the study. The instrument was submitted to experts in ICT and Education for both face and content validation. The reliability of the instrument was established using Cronbach Alpha the instrument yielded a reliability coefficient of 0.87 . The questionnaire had four sections. Sections one and four were for both lecturers and students; section two for lecturers only and section three for students only. The questionnaire used four-point rating scale. Mean was used to analyze the data collected. The cut-off point for accepting or rejecting an item was fixed at 2.50. Therefore, items with mean rating below 2.50 were rejected and items with mean rating of 2.50 and above were accepted. The hypotheses were tested at 0.05 level of significance using t-test statistic. 


\section{Findings and Results}

\subsection{Research Question 1}

To what extent are e-learning infrastructures adequate in UI?

Table 1: Adequacy of ICT infrastructures in UI.

\begin{tabular}{|c|l|r|r|r|r|}
\hline S/N & ITEMS & $\mathbf{X}_{1}$ & $\mathbf{X}_{2}$ & $\mathbf{X t}$ & REMARKS \\
\hline 1 & Internet services provided by the university are adequate & 1.75 & 1.75 & 1.71 & Disagreed \\
\hline 2 & Internet services provided by the university are fast & 2.45 & 2.43 & 2.44 & Disagreed \\
\hline 3 & Internet services provided by the university are reliable & 1.80 & 1.75 & 1.76 & Disagreed \\
\hline 4 & Internet services can be easily accessed Outside the university (private cyber cafes). & 3.68 & 3.57 & 3.63 & Agreed \\
\hline 5 & The university's digital library is efficient. & 1.98 & 2.23 & 2.11 & Disagreed \\
\hline 6 & Educational materials could be accessed from the university's website. & 1.30 & 1.25 & 1.28 & Disagreed \\
\hline 7 & Links to educational resources websites and e-journals can be found on the university's website. & 1.55 & 1.89 & 1.72 & Disagreed \\
\hline 8 & Students can easily get access to a computer in the ICT center or within the university. & 1.40 & 1.90 & 1.65 & Disagreed \\
\hline 9 & Multimedia projectors are available in the university. & 1.65 & 2.00 & 1.83 & Disagreed \\
\hline 10 & Interactive white boards are available in the University. & 1.59 & 1.60 & 1.60 & Disagreed \\
\hline 11 & Computers are adequately provided. & 1.24 & 1.24 & 1.18 & Disagreed \\
\hline 12 & Television sets are available. & 1.47 & 1.51 & 1.49 & Disagreed \\
\hline 13 & Digital Video Disk players are available. & 1.39 & 1.34 & 1.37 & Disagreed \\
\hline 14 & Flash drives/External Hard drives are adequately provided. & 1.24 & 1.22 & 1.23 & Disagreed \\
\hline 15 & E-books are adequately provided. & 1.03 & 1.05 & 1.04 & Disagreed \\
\hline 16 & Software is sufficiently provided. & 1.59 & 1.44 & 1.52 & Disagreed \\
\hline 17 & Printers are adequately provided. & 1.56 & 2.00 & 1.78 & Disagreed \\
\hline
\end{tabular}

$\mathrm{X} 1=$ mean score for lecturers; $\mathrm{X} 2=$ mean score for students $\mathrm{Xt}=$ mean of teachers and lecturers

The result in table 1 shows that 16 items were disagreed because their mean scores were below 2.50. Only item 4 was agreed with mean score of 3.68 and 3.57 from lecturers and students

\subsection{Research Question 2}

How proficient are lecturers in the use of e-learning infrastructures in teaching and learning?

Table 2: Lecturers' proficiency in the use of e-learning infrastructures for teaching and learning.

\begin{tabular}{|c|l|c|c|}
\hline S/NO & ITEMS & X & REMARK \\
\hline 1 & Lecturers can use the internet efficiently. & 2.84 & Agreed \\
\hline 2 & Lecturers use the internet to facilitate teaching and learning & 3.00 & Agreed \\
\hline 3 & Lecturers prefer the internet to books when sourcing for academic information. & 2.26 & Disagreed \\
\hline 4 & Lecturers are versatile in the use of computer applications in enhancing teaching. & 2.15 & Disagreed \\
\hline 5 & Lecturers individually or collectively have Webpages. & 1.83 & Disagreed \\
\hline 6 & Lecturers individually or collectively have Blogs/Wikis. & 1.32 & Disagreed \\
\hline 7 & Lecturers individually or collectively have e-mail accounts. & 3.90 & Disagreed \\
\hline 8 & Lecturers individually or collectively have e-journals. & 1.10 & Disagreed \\
\hline 9 & Online colllaboration/teleconference are employed by lecturers to enhancing teaching. & 1.06 & Disagreed \\
\hline 10 & Computerized diagnostic assessment is used by lecturers in assessing students & 1.10 & Disagreed \\
\hline 11 & Lecturers provide educational literature to students in soft copies & 1.31 & Disagreed \\
\hline 12 & Lecturers refer students to the internet to solve assignments. & 3.04 & Agreed \\
\hline 13 & Lecturers refer students to specific sites on the internet for academic information & 1.47 & Disagreed \\
\hline 14 & Lecturers refer students to specific sites on the internet for academic information & 1.29 & Disagreed \\
\hline 15 & Lecturers use computer simulations to aid teaching and Learning & 1.05 & Disagreed \\
\hline 16 & Lecturers use electronic devices to facilitate retention in Learning & 1.58 & Disagreed \\
\hline 17 & Lecturers source for updated educational materials online. & 2.29 & Disagreed \\
\hline 18 & Lecturers partner with other scholars online for educational purpose. & 1.85 & Disagreed \\
\hline 19 & Lecturers have electronic devices that could access, store, send, manipulate and read information. & 3.42 & Agreed \\
\hline
\end{tabular}


The result in table 2 shows that fourteen out of nineteen items were disagreed because their mean was below 2.50. Four items were agreed.

\subsection{Research Question 3:}

How proficient are students in the use of e-learning infrastructures to enhance their learning?

Table 3: Students' Proficiency in the use of e-learning infrastructures to enhance learning

\begin{tabular}{|c|c|c|c|}
\hline S/NO & ITEMS & $\mathrm{X}$ & REMARK \\
\hline 1 & Students are aware of the internet. & 3.64 & Agreed \\
\hline 2 & Students browse the internet frequently. & 2.79 & Agreed \\
\hline 3 & Students can use the internet effectively. & 2.55 & Agreed \\
\hline 4 & Students prefer the internet to books when sourcing for academic information. & 2.36 & Disagreed \\
\hline 5 & Students browse the internet for academic information. & 2.51 & Agreed \\
\hline 6 & Students browse the internet for school registration purpose. & 3.94 & Agreed \\
\hline 7 & Students browse the internet to download games/movies/ Music & 3.40 & Agreed \\
\hline 8 & Students browse to get news/sports/fashion information. & 3.38 & Agreed \\
\hline 9 & Students partner with other students online for academic information. & 1.70 & Disagreed \\
\hline 10 & Online chats between students are for academic purposes. & 1.55 & Disagreed \\
\hline 11 & Students' record lectures in class, using electronic devices, for future reference. & 1.78 & Disagreed \\
\hline 12 & Students have e-mails. & 3.39 & Agreed \\
\hline 13 & Students prefer reading hard copies of educational Materials to soft copies. & 2.71 & Agreed \\
\hline 14 & $\begin{array}{l}\text { Students have electronic devices (computers, mobile phones, etc.) that could access, store, send, } \\
\text { manipulate and read audio and visual information. }\end{array}$ & 3.22 & Agreed \\
\hline
\end{tabular}

Table 3 revealed that the mean score rating of the responses of the respondents for four items ranked below the cut-off point of 2.50 while the mean score of the remaining ten items were above 2.50 .

\subsection{Research Question 4:}

What are the factors that inhibit the use of e-learning infrastructures in UI?

Table 4: Factors that inhibit the use of e-learning infrastructures in UI

\begin{tabular}{|c|l|c|c|c|c|}
\hline S/NO & ITEMS & $X_{1}$ & $X_{2}$ & $X_{t}$ & REMARKS \\
\hline 1 & High cost is a factor that deter the use of the internet by students and lecturers & 3.37 & 3.54 & 3.46 & Agreed \\
\hline 2 & High cost of 'air time' affects the use of internet Services & 3.63 & 3.73 & 3.69 & Agreed \\
\hline 3 & High cost of purchasing relevant materials online discourages internet usage. & 3.28 & 3.51 & 3.40 & Agreed \\
\hline 4 & High cost of maintaining electronic devices discourages their use for learning. & 2.72 & 3.01 & 2.87 & Agreed \\
\hline 5 & Funds are insufficient for the development of e-learning infrastructures. & 3.08 & 2.60 & 2.84 & Agreed \\
\hline 6 & $\begin{array}{l}\text { Lack of manpower to maintain Information Communication Technology (ICT) infrastructures } \\
\text { affect their use. }\end{array}$ & 2.70 & 2.64 & 2.67 & Agreed \\
\hline 7 & Too many restrictions in accessing relevant educational materials. & 2.55 & 3.23 & 2.89 & Agreed \\
\hline 8 & Poor power supply affects the use of electronic Devices for teaching and learning. & 3.86 & 3.75 & 3.81 & Agreed \\
\hline 9 & Relevant materials are difficult to find on the internet. & 2.59 & 3.14 & 2.87 & Agreed \\
\hline 10 & Lecturers prefer the 'talk and chalk' method of teaching. & 2.83 & 3.88 & 3.36 & Agreed \\
\hline 11 & Use of electronic devices encourages laziness in students. & 1.70 & 1.10 & 1.40 & Disagreed \\
\hline 12 & $\begin{array}{l}\text { Unavailability of time affects lecturers tendency to develop educational computer applications } \\
\text { to aid teaching and learning. }\end{array}$ & 2.98 & 3.09 & 3.04 & Agreed \\
\hline 13 & $\begin{array}{l}\text { Contention between the school and lecturers on Intellectual property right is a factor that } \\
\text { discourages the development of computer applications to enhance teaching. }\end{array}$ & 3.00 & 2.61 & 2.81 & Agreed \\
\hline 14 & Lecturers may lose class control if e-learning is encouraged. & 1.60 & 1.34 & 1.47 & Disagreed \\
\hline
\end{tabular}

$\mathrm{X} 1$ = mean score of lecturers, $\mathrm{X} 2 \mathrm{~m}$ mean score of students $\mathrm{Xt}=$ mean score of lecturers and students

Table 4 shows that the mean score rating of the responses of respondents range from 1.10 to 3.88 . All items ranked above the cut-off point except items 11 and 14 which ranked below the cut-off point. 


\subsection{Hypothesis 1:}

There is no significant difference in the mean response of lecturers and students on the availability of e-learning Infrastructures

Table 5: t-test analysis of mean responses of lecturers and students on the availability of e-learning infrastructures in UI.

\begin{tabular}{|c|c|c|c|c|c|}
\hline Respondent & $\mathrm{X}$ & $\mathrm{N}$ & $\mathrm{Df}$ & $\boldsymbol{t}$-cal & $\mathrm{t}$-table \\
\hline \multirow{2}{*}{ Lecturers Students } & 1.68 & 182 & \multirow{2}{*}{562} & \multirow{2}{*}{0.78} & \multirow{2}{*}{1.96} \\
& 1.76 & 382 & & \\
\hline
\end{tabular}

\subsection{Summary of findings}

1. There are no adequate e-learning infrastructures for effective teaching and learning in UI. However, internet services can easily be accessed outside the university premises.

2. Lecturers have electronic devices and laptops that could facilitate e-learning but cannot effectively use these devices to teach.

3. Students have electronic devices and laptops that could facilitate e-learning but are ineffective in using them for learning purposes.

4. The major constraints to the provision and use of e-learning infrastructures for teaching and learning in $\mathrm{UI}$ are poverty, poor funding, and poor electric power supply in and around the university. Also, resistance to change on the part of lecturers inhibits the use of e-learning infrastructures for teaching and learning.

\section{Discussion of Findings}

Finding from table 1 showed that internet service is provided by the management of U.I; however, the services are not fast, reliable or adequate. Nonetheless, services can be accessed outside the university in cyber cafes. Furthermore, the table revealed that the university's website was not designed to promote teaching and learning but to divulge information about the university and enable students to register online. This is in agreement with the findings of Kamba (2009) who stated that Nigerian universities are in the trend of creating web pages which are meant for advertisement of the university and not for e-learning activities. In addition, the findings of this study revealed that e-learning equipment such as interactive white boards, computers, projectors, TV sets, and printers are not adequately provided by the university. This is a reflection of the emphasis being placed on e-learning in the university. Pirani (2004) stated that for an institution to be able to adopt e-learning, it must provide adequate and reliable technical infrastructures. From the above, it can be seen that e-learning infrastructures are inadequately provided in $\mathrm{UI}$ for effective teaching and learning. Findings in table 2 revealed that lecturers are aware of the internet and can surf the web. But they cannot use it in facilitating the teaching and learning. UNESCO (2002) and Pirani (2004) are of the view that instructors need to know when, how and where to use ICT to enhance knowledge acquisition. The table further revealed that lecturers own electronic devices that could manipulate, store, retrieve, send, receive, copy, edit and display Information such as television sets, computers, PDAs, etc. However, these devices are not used for educational purposes. According to UNESCO (2002), the key to the use of ICT for educational purpose is not in ICT itself, but in understanding and strategically and logically employing it to meet educational goals. This proves that lecturers may have idea of ICT but may not be effective in using them to facilitate teaching; which may be attributed to inadequate training in the use of ICT for teaching.

Wodi (2009) and Ololube (2006) are of the opinion that since the ICT industry is very dynamic, there is the need for continuous aggressive training programmes to catch up with frontiers of knowledge, creativity and innovation. Findings in table 3 revealed that students know how to use the internet and frequently surf the web. However, the students use the internet for social purposes and not for sourcing academic information. Despite the fact they have electronic devices that can store, access, send, manipulate and read audio-visual information; they do not use them to record and share lectures. According to Wodi (2009), computer skill is necessary to undergraduates for them to effectively appreciate the benefits of programmed learning and computer assisted instruction. He said this is core aspect of ICT where the learner can manipulate ICT hardware and software gadgets to support their personalized instruction and data gathering. This is in agreement with the findings of this study which shows that students have computer skill but cannot use them for personalized learning. This calls for more training for the students as well.

Table 4 indicates that the high cost of e-learning infrastructures, high cost of 'air time', materials, maintenance of 
gadgets; insufficient funds, lack of skilled manpower, poor power supply, lecturers preference to 'talk and chalk' as opposed to the use of e-learning facilities, and so on hinder the use of e-learning infrastructures. This is in line with the findings of Nbina, Obomanu and Vikoo (2011) who found that lecturers have no knowledge of ICT facilities and so shy away from utilizing them for teaching. Also, Akinnuwesi, Adedoyin, and Adegoke (2007) are of the view that implementation of e-learning will require major commitment of resources and the support of stakeholders in the public and private sectors. Moreover, sufficient funds are needed to establish and maintain e-learning facilities in schools.

\section{Conclusion}

It has been noted that e-learning is the application of internet to enhance learning. This study revealed that e-learning infrastructures are not available in University of Ibadan. Therefore, ICT infrastructures should be provided to facilitate effective teaching and learning in order to brace up to present day educational challenges. Efforts should be made towards tackling other factors that are militating against the usage of e-learning infrastructures. It is safe to conclude here that unless these facts are seriously taken into consideration and acted upon, education in U.I will only retrogress in a progressive world.

\section{Recommendations}

Based on the findings of this study, the following recommendations are made to help improve e-learning usage in U.I.

1. Lecturers should be well trained in specific methods in which they could use electronic devices to enhance teaching. This could be achieved by contracting experts to develop curricular for training process.

2. Curricular for teaching that will inculcate the use of e-learning infrastructures by students should be developed.

3. Adequate power supply should be provided in and around the school to stimulate the use of electronic devices for teaching and learning.

4. The university should enter into contracts with internet service providers such as MTN, Airtel, Etisalat and Glo so that they can have reliable internet services for lecturers and students.

5. The university should liaise or register with organizations that have or publish educational resources or websites for easy access of educational materials from these websites.

6. The university should upgrade her website or launch a website which lecturers and students can use to disseminate or access information. Such website should enable lecturers to upload their course materials. Past projects should also be uploaded on the websites for easy access to both lecturers and students. The website should also freely host wikis/blogs and e-journals of the university.

7. The university should also liaise with private organizations to provide cheap electronic devices for students and lecturers. These electronic devices does not necessarily have to be laptops that are expensive but other electronic devices that could store, copy, display, record information such as MP5, WAP enabled phones, PDAs, etc., In addition, proper orientation should also be given to students on how to use these devices to promote learning.

\section{References}

Akinnuwesi, B., Adedoyin, A. A. \& Adegoke, M. A. (2007). A framework of Information and Communications Technology (ICT) for education in Nigeria. International Journal of Science and Technology. 3(43):34.47

Agyeman, O. T. (2007). ICT for Education in Nigeria. Retrieved on 13th April, 2012 from www.infodev.org.

Erah, P. O. (2006). Introduction to e-learning protocols. Paper presented at ETF capacity building workshop for lecturers of universities in Nigeria at the University of Uyo.

Freedman, A. (2001). Computer Desktop Encyclopedia (version 14.3m). New York: The computer language company Inc.

Forcheri, P \& Molfino, M. T. (2000): ICT as a tool to learning to learn. Education Technology 3(45):45-57

Kamba, A. M. (2009). Problems, challenges and benefits of implementing e-learning in Nigerian universities: An empirical study. International Journal of Emerging Technologies in Learning (IJET). 4 (1) 11 - 23.

Nbina, J. B., Obomanu, B. J. \& Vikoo, B. (2011). Utilization of Information and Communication Technology for quality instruction in Rivers State University of Education Port Harcourt: An Assessment. Journal of Emerging Trends in Educational Research and Policy Studies (JETERAPS) 2 (1):74 - 80.

Newhouse, C. P. (2002a). The Impact of ICT on Learning and Teaching. Australia: Specialist Educational Services.

Newhouse, C. P. (2002b). A Framework to Articulate the Impact of ICT on Learning in Schools. Australia: Specialist Educational Services. 
Ololube, P. N. (2006). Appraising the relationship between ICT usage and integration and the standard of teacher education programs in a developing economy. International Journal of Education and Development using Information and Communication Technology (IJEDICT). 2 (3):70 - 85

Pajo, C. \& Wallace, A. (2001).Barriers to the uptake of web-based technology by university teachers. Journal of distant education 16:7084.

Pirani, A. J. (2004). Supporting e-learning in higher education: road map, tools for navigating complex decisions. EDUCAUSE Centre for Applied Research. Retrieved on 13th May, 2009 from www.educause.edu/edcar/.

Pulkkinen, J. (2007).Cultural globalization and integration of ICT in education. In K. Kumpulainen (Ed.), Educational technology: Opportunities and challenges (pp.13-23). Oulu, Finland: University of Oulu.

Rosenberg, M. (2001). E-learning: Strategies for Delivering Knowledge in Digital Age. USA: McGraw-Hill.

Rosswall T. (1999). The role of ICT in higher education at the beginning of this new millennium. www.emeraldinsight.com/journals.htm?articleid=1921979

Shahadat, H. Muhbub, H. \& Clement, C. (2012). Barriers to the introduction of ICT into Education in Developing Countries: The example of Bangladesh. International Journal of instruction. Vol. No. 2.

UNESCO (2002). Information and Communication Technology in Education: A Curriculum for Schools and Programme for Teacher Development. Paris: UNESCO Division of Higher Education.

Volman, M. \& Van Eck, E. (2001).Gender Equity and Information Technology in Education: The Second Decade. Review of Educational Research. 71(4): 613-634.

Voogt, J. (2003) Consequences of ICT for Aims, Contents, Processes and Environments of learning. http://link.springer.com/ chapter/10.1007\%2F978-94-017-1205-7_13\#page-1

Wodi, S. W. (2009). The concept of educational technology: problems and prospects of Information and Communication Technology (ICT) in Nigeria. International Journal of African Studies. 1 (1): $4-10$.

Wood, D. (1995). The theory, training, and technology: Education and Training, 37(1), 12-16 